\title{
Hubungan Vulva Hygiene Dengan Kecepatan Penyembuhan Luka Perineum Ibu Nifas Di BPM Yuliani S.ST
}

\author{
Lilik Darwati ${ }^{1}$ \\ ${ }^{1}$ Program Studi Diploma III Kebidanan Universitas Islam Lamongan \\ lilikdarwati@unisla.ac.id
}

\begin{abstract}
ABSTRAK
Kejadian robekan perineum pada ibu nifas saat bersalin setiap tahunnya semakin meningkat dan mengalami penyembuhan luka yang lama. Hal ini dipengaruhi beberapa faktor salah satunya yaitu vulva hygiene. Berdasarkan survey awal yang dilakukan diBPM Yuliani S.ST di lakukan secara wawancara dan obserfasi dari $10(100 \%)$ ibu nifas didapatkan $7(70 \%)$ ibu nifas yang penyembuhan luka perineumnya lebih dari 7 hari, wawancara lebih lanjut diketahui ibu yang tidak melakukan vulva hygiene dengan benar karena takut akan menyentuh luka jahitan dan takut apabila terlalu sering terkena air jahitan akan sembuh semakin lama.

Desain penelitian Analitik Korelasional dengan metode Cohort. Populasi seluruh ibu nifas yang mengalami luka jahitan perineum di BPM Yuliani S.ST sebesar $35 \mathrm{ibu}$ nifas. Metode sampling menggunakan Consecutive Sampling.Variabel independen vulva hygiene dan variabel dependen kecepatan penyembuhan luka perineum pada ibu nifas. Data penelitian diperoleh melalui kuesioner tertutup dan lembar observasi luka perineum. Data ditabulasi dan dianalisis menggunakan uji Fisher's Exact Test.

Hasil penelitian menunjukkan $\mathrm{p}=0,000, \alpha=0,05 \mathrm{p}<\alpha$ dimana $\mathrm{H}_{1}$ diterima artinya ada hubungan vulva hygiene dengan kecepatan penyembuhan luka perineum pada ibu nifas ada hubungan yang signifikan. Diharapkan penelitian ini meningkatkan peran tenaga kesehatan memberikan KIE tentang vulva hygiene sehingga penyembuhan luka perineum ibu nifas.
\end{abstract}

Kata Kunci :Vulva hygiene, penyembuhan luka perineum.

\begin{abstract}
The incidence of perineal tears in postpartum mothers during childbirth is increasing every year and has a long wound healing. This is influenced by several factors, one of which is vulva hygiene. Based on the initial survey conducted at BPM Yuliani S.ST conducted by interview and observation of 10 (100\%) puerperal mothers found 7 (70\%) puerperal mothers who healing perineal wounds more than 7 days, further interviews known to mothers who did not do vulva hygiene correctly for fear of touching the suture wound and afraid that if it is too often exposed to water the stitches will heal for longer.

Correlational Analytic research design with the Cohort method. The population of all postpartum mothers who suffered perineal suture injuries in BPM Yuliani S.ST was 35 postpartum mothers. The sampling method uses consecutive sampling. Valuable independent variables are hygiene and the dependent variable is the speed of perineal wound healing in postpartum mothers.
\end{abstract}


The research data were obtained through a closed questionnaire and perineum wound observation sheet. Data were tabulated and analyzed using the Fisher's Exact Test.

The results showed $p=0,000, \alpha=0.05 p<\alpha$ where $H 1$ was accepted meaning there was a relationship of vulva hygiene with the speed of healing of perineal wounds in postpartum mothers there was a significant relationship. It is hoped that this research will increase the role of health workers in providing IEC about vulva hygiene so that the healing of puerperal perineal wounds.

Keywords: Vulva hygiene, healing of perineal wounds.

\section{PENDAHULUAN}

Masa Nifas (puerperium) merupakan masa setelah keluarnya plasenta sampai alat-alat reproduksi pulih sebelum hamil dan secara normal, masa nifas berlangsung selama 6 minggu atau 40 hari. Pada masa puerperium alat-alat reproduksi harus dirawat dengan baik agar dapat mencegah terjadinya infeksi pada masa post partum (Ambarwati, 2010).

Luka pada perineum akibat episiotomi, ruptur atau laserasi merupakan daerah yang tidak mudah untuk dijaga agar tetap bersih dan kering. Perawatan luka perineum bagi ibu nifas difokuskan untuk mengurangi rasa ketidaknyamanan, menjaga kebersihan, mencegah infeksi dan meningkatkan penyembuhan luka perineum. Perawatan luka perineum dapat dilakukan dengan menggunakan air bersih yang mengalir dan dapat ditambah denganlarutan antiseptic 23 kali sehari, yaitu pada saat mandi, setelah buang air kecil atau b.a.k dan setelah buang air besar atau b.a.b. Semua aspek pada perawatan nifas dilaksanakan berdasarkan upaya untuk mempertahankan hygiene serta kenyamanan klien dan mencegah infeksi.

Berdasarkan data World Health Organization (WHO) pada tahun
2017 terjadi 2,9 juta kasus robekan perineum pada ibu bersalin. Angka ini diperkirakan mencapai 6,8 juta pada tahun 2050 jika bidan yang tidak melakukan asuhan kebidanan dengan baik. Prevalensi ibu bersalin yang mengalami rupture perineum. Di Indonesia laserasi perineum dialami oleh $75 \%$ ibu melahirkan pervaginam. Pada tahun 2017 menemukan bahwa dari total 1951 kelahiran spontan pervaginam, $57 \%$ ibu mendapat jahitan perineum (28\% karena episiotomi dan 29\% karena robekan spontan). Berdasarkan data di Jawa Timur angka kejadian ruptur perineum pada tahun 2012 sebanyak 54 kasus, tahun 2013 sebanyak 24 kasus, tahun 2014 sebanyak 17 kasus, tahun 2015 sebanyak 100 kasus, tahun 2016 sebanyak 95 kasus (Depkes RI, 2017).

Berdasarkan survey yang dilaksanakan di PBM Yuliani S.ST Banjarmendalan Kec. Lamongan Kabupaten Lamongan diperoleh data bulan September 2018 dari 25 diperoleh 10 ibu post partum yang mengalami robekan perineum, 7 $(70 \%)$ diantaranya mengalami keterlambatan penyembuhan luka (sembuh lebih dari 7 hari), sedangkan $3(30 \%)$ orang mengalami penyembuhan luka perineum yang normal dimana luka sembuh antara 6 sampai 7 hari. Dari data tersebut 
dapat diketahui bahwa masih ada ibu yang mengalami keterlambatan penyembuhan luka perineum.

Secara umum ada 2 faktor yang mempengaruhi penyembuhan luka perineum meliputi faktor internal dan faktor eksternal menurut Smeltzer (2010). Faktor internal meliputi (1) Gizi yaitu makanan yang bergizi dan sesuai porsi akan menyebabkan ibu dalam keadaan sehat dan segar dan akan mempercepat masa penyembuhan, (2) Personal hygiene yaitu sangat mempengaruhi penyembuhan luka perineum, jika kebersihan diri pada ibu nifas kurang terjaga akan menyebabkan adanya benda asing seperti debu dan kuman, (3) Kondisi ibu yaitu kondisi kesehatan, baik secara fisik maupun mental, mempengaruhi lama penyembuhan. Jika kondisi ibu sehat, maka ibu dapat merawat diri sendiri dengan baik, (4) Keturunan atau sifat genetik seseorang dapat mempengaruhi karena kemampuan dalam sekresi insulin terhambat sehingga glukosa darah meningkat dan terjadi penipisan protein dan kalori,(5) Usia yaitu semakin tua usia seseorang akan semakin menurun kecepatan penyembuhan lukanya penyembuhan luka lebih cepat terjadi pada usia muda daripada usia tua, (6) Hemoragi yaitu akumulasi darah menciptakan ruang rugi juga sel-sel mati yang harus disingkirkan. Area menjadi pertumbuhan untuk infeksi,(7) Hipovolemi yaitu volume darah yang tidak mencukupi mengarah pada vasokonstriksi dan penurunan oksigen dan nutrient yang tersedia untuk penyembuhan luka, (8) faktor lokal edema yaitu penurunan suplai oksigen melalui gerakan meningkatkan tekanan interstisial pada pembuluh, (9) Defisit nutrisi yaitu sekresi insulin dapat dihambat, sehingga menyebabkan glukosa darah meningkat, sehingga dapat terjadi penipisan protein-kalori, (10) Defisit oksigen, Insufisien oksigenasi jaringan yaitu oksigen yang tidak memadai dapat diakibatkan tidak adekuatnya fungsi paru dan kardiovaskuler juga vasokonstriksi setempat. Penumpukan drainase yaitu sekresi yang menumpuk menganggu proses penyembuhan, (11) Over aktivitas juga dapat menghambat perapatan tepi luka sehingga mengganggu penyembuhan yang diinginkan.

Sedangkan faktor eksternal meliputi (1) Penanganan petugas, bidan merupakan petugas kesehatan di sebuah desa yang melayani masyarakat. Bantuan terbaik seorang petugas kesehatan adalah dengan cara memahami bahwa klien adalah manusia yang membutuhkan perhatian dan bantuan. (2) Penanganan jaringan yaitu penanganan yang kasar menyebabkan cedera dan memperlambat penyembuhan. (3) Obat-obatan yaitu dapat mempengaruhi penyembuhan luka misalnya steroid dapat menyamarkan adanya infeksi dengan menganggu respon inflamasi normal, antikoagulan dapat menyebabkan hemoragi, antibiotil sprektrum luas atau spesifik, efektif bila segera sebelum pembedahan untuk patologi spesifik atau kontaminasi bakteri. Jika diberikan setelah luka ditutup, tidak efektif karena koagulasi intravaskuler (Nugroho dkk, 2014). Penyebab keterlambatan penyembuhan luka perinuem yaitu pengetahuan ibu yang kurang tentang penyembuhan luka dimana ibu takut melakukan mobilisasi lebih dini, faktor budaya yang sudah melekat 
sejak dulu sering dijadikan patokan selama masa nifas seperti halnya pantangan terhadap beberapa makanan tertentu dan lebih pada individu itu sendiri diantaranya, malnutrisi serta keadaaan lingkungan yang kurang bersih.

Keterlambatan penyembuhan luka perineum dapat mengakibatkan, yang pertama adalah terjadinya infeksi, kondisi perineum yang terkena lochea dan lembab akan sangat menunjang perkembangan bakteri yang dapat menyebabkan timbulnya infeksi pada perineum. Yang kedua terjadi komplikasi, munculnya infeksi pada perineum dapat merambat pada saluran kandung kemih ataupun pada jalan lahir yang dapat berakibat pada munculnya komplikasi infeksi kadung kemih maupun infeksi pada jalan lahir. Infeksi nifas yang dapat terjadi sebagai akibat komplikasi luka perineum antara lain metritis, endometritis, bahkan sampai abses pelvis. Ketiga, adalah terjadinya kematian ibu postpartum, penanganan komplikasi yang lambat dapat menyebabkan terjadinya kematian pada ibu post partum mengingat kondisi fisik ibu post partum masih lemah (Ambarwati, 2010).

Akibat perawatan perineum yang kurang baik mengakibatkan kondisi perineum yang terkena lochea menjadi lembab dan akan sangat menunjang perkembangbiakan bakteri yang menyebabkan timbulnya infeksi pada perineum yang dapat menghambat proses penyembuhan luka. Biasanya penyembuhan luka pada robekan perineum ini akan sembuh bervariasi, ada yang sembuh normal dan ada yang mengalami kelambatan dalam penyembuhannya, hal ini dipengaruhi oleh beberapa hal diantaranya karakteristik ibu bersalin, status gizi, kondisi perlukaan dan perawatannya (Rukiyah, 2014).

Untuk mengatasi masalah di atas, maka dapat dilakukan dengan cara memberikan infomasi kepada keluarga tentang kebutuhan ibu selama nifas yang berkaitan dengan personal hygiene terutama pada kebersihan vulva. Sedangkan peran petugas kesehatan juga perlu memberikan penyuluhan atau demonstrasi tentang perawatan vulva hygiene yang benar pada luka perineum dan mengajarkan ibu nifas caravulva hygiene dengan benar.Selain bidan keluarga juga harus ikut serta memberi tahu kepada ibu nifas. Dari uraian di atas maka penelitian tertarik untuk melakukan penelitian tentang "Hubungan Vulva hygiene dengan Kecepatan Penyembuhan Luka Perineum Pada Ibu Nifas Di BPM Bidan Yuliani S.ST Banjarmendalan Kec. Lamongan Kabupaten Lamongan.

\section{Rumusan Masalah}

Berdasarkan identifikasi dan latar belakang masalah dapat dirumuskan pertanyaan masalah penelitian sebagai berikut: "Apakah ada Hubungan Vulva hygiene dengan Kecepatan Penyembuhan Luka Perineum Pada Ibu Nifas Di BPM Bidan Yuliani S.ST Banjarmendalan Kec. Lamongan Kabupaten Lamongan?"

\section{METODE PENELITIAN}

Desain penelitian yang digunakan adalah Analitic Corelasional yaitu suatu metode dimana peneliti dapat mencari, menjelaskan suatu hubungan, memperkirakan dan menguji 
berdasarkan teori yang ada dan bertujuan untuk mengungkapkan hubungan kolerasi antar variabel (Nursalam, 2013). Pendekatan yang digunakan dalam penelitian ini adalah Cohort dimana peneliti pengambilan data variabel independen dilakukan terlebih dahulu, setelah beberapa waktu kemudian baru dilakukan pengambilan data variable dependen (Nursalam, 2008).

\section{HASIL PENELITIAN}

\subsection{Data Umum}

\section{Karakteristik Ibu Nifas Di PBM}

\section{Yuliani S.ST}

1) Umur

Tabel 4.1 Distribusi Umur Ibu Nifas di BPM Bidan Yuliani S.ST Banjarmendalan Kec. Lamongan Kabupaten

\begin{tabular}{|c|c|c|c|}
\hline No & Umur & Frekuensi & $\begin{array}{l}\text { Persentase } \\
(\%)\end{array}$ \\
\hline 1 & $\begin{array}{l}<21 \\
\text { Tahun }\end{array}$ & 3 & 9,1 \\
\hline 2 & $\begin{array}{l}21-35 \\
\text { Tahun }\end{array}$ & 22 & 66,7 \\
\hline 3 & $\begin{array}{l}>35 \\
\text { Tahun } \\
\text { Jumlah }\end{array}$ & 33 & 24,2 \\
\hline
\end{tabular}

Dari tabel 4.1 dapat dijelaskan bahwa sebagian besar ibu nifas berumur $21-35$ tahun yaitu sebanyak 22 orang atau $66,7 \%$ dan sebagian kecil berumur $<21$ tahun sebanyak 3 orang atau $9,1 \%$.

2) Jumlah Anak

Tabel 4.2 Distribusi Jumlah Anak Ibu Nifas di BPM Bidan Yuliani S.ST Banjarmendalan Kec. Lamongan Kabupaten Lamongan. Tahun 2019

\begin{tabular}{llll}
\hline No & $\begin{array}{l}\text { Jumlah } \\
\text { Anak }\end{array}$ & Frekuensi & $\begin{array}{l}\text { Persentase } \\
(\%)\end{array}$ \\
\hline 1 & 1 & 5 & 15,2 \\
2 & $2-3$ & 25 & 75,7 \\
3 & $\geq 3$ & 3 & 9,1 \\
& Jumlah & 33 & 100 \\
\hline
\end{tabular}

Dari tabel 4.2 didapatkan hampir seluruh 25 atau $75,7 \%$ jumlah anak pada ibu nifas 2-3 dan sebagian kecil 3 atau $9,1 \%$ jumlah anak pada ibu nifas $\geq 3$.

\section{3) Pendidikan}

Tabel 4.3 Distribusi Pendidikan Ibu Nifas di Di BPM Bidan Yuliani S.ST Banjarmendalan Kec. Lamongan Kabupaten Lamongan Tahun 2019

\begin{tabular}{llll}
\hline No & Pendidikan & Frekuensi & $\begin{array}{l}\text { Persentase } \\
(\%)\end{array}$ \\
\hline 1 & SD & 0 & 0 \\
& Sederajat & & \\
2 & SMP & & \\
& Sederajat & 12 & 36,4 \\
3 & SMA & 18 & 54,5 \\
& Sederajat & & \\
4 & PT & 3 & 9,1 \\
& Sederajat & & \\
& Jumlah & 33 & 100 \\
\hline & Dari tabel & 4.3 & dapat dijelaskan
\end{tabular}
bawa hampir seluruhnya ibu nifas berpendidikan SMA 18 orang atau $54,5 \%$ dan tidak satupun ibu nifas berpendidikan SD sederajat 0 orang atau $0 \%$.

4) Pekerjaan Ibu

Tabel 4.4 Distribusi Pekerjaan Ibu Nifas di BPM Bidan Yuliani S.ST Banjarmendalan Kec. Lamongan Kabupaten Lamongan. Tahun 2019

\begin{tabular}{llll}
\hline No & $\begin{array}{l}\text { Pekerjaan } \\
\text { Ibu }\end{array}$ & Frekuensi & $\begin{array}{l}\text { Persentase } \\
(\%)\end{array}$ \\
\hline 1 & IRT & 16 & 48,5 \\
2 & Petani & 10 & 30,3 \\
3 & Wiraswasta & 6 & 18,2 \\
4 & Swasta & 1 & 3,0 \\
& Jumlah & 33 & 100 \\
\hline
\end{tabular}


Dari tabel 4.4 dapat dijelaskan bawa hampir sebagian ibu nifas Ibu Rumah Tangga 16 orang atau $48,5 \%$ dansebagian kecilibu nifas pekerjaan swasta 1 orang atau $3,0 \%$.

\subsubsection{Data Khusus}

1) Vulva hygiene pada ibu nifas di BPM Yuliani S.ST

Tabel 4.5 Distribusi Frekuensi Vulva hygiene Ibu Nifas di BPM Bidan Yuliani S.ST Banjarmendalan Kec. Lamongan Kabupaten Lamongan. Tahun 2019

\begin{tabular}{llcc}
\hline No & Perilaku & Frekuensi & $(\%)$ \\
\hline 1 & Benar & 16 & 48,5 \\
2 & Salah & 17 & 51,5 \\
& Jumlah & 33 & 100 \\
\hline
\end{tabular}

Dari tabel 4.5 dapat dijelaskan bahwa sebagian besar ibu nifas 17 orang atau $51,5 \%$ melakukan vulva 3 ) hygiene salah.
2) Proses Kecepatan Penyembuhan Luka Perineum pada ibu nifas di BPM Yuliani S.ST

Tabel 4.6 Distribusi Frekuensi

Kecepatan Penyembuhan Luka Perineum Ibu Nifas di BPM Bidan Yuliani S.ST Banjarmendalan Kec. Lamongan Kabupaten Lamongan. Tahun 2019

\begin{tabular}{llcl}
\hline No & $\begin{array}{l}\text { Penyembuhan } \\
\text { luka perineum }\end{array}$ & Frekuensi & $\begin{array}{l}\text { Presentase } \\
(\%)\end{array}$ \\
\hline 1 & Cepat & 15 & 45,5 \\
2 & Lambat & 18 & 54,5 \\
& Jumlah & 33 & 100 \\
\hline
\end{tabular}

Tabel 4.6 dapat diketahui bahwa sebagian besar ibu nifas 18 orang atau 54,5\% kecepatan penyembuhan luka perineum lambat.

Hubungan Vulva hygiene dengan Kecepatan Penyembuhan Luka Perineum di BPM Yuliani S.ST

Tabel 4.7 Hubungan Vulva hygiene dengan kecepatan penyembuhan luka perineum pada Ibu Nifas di BPM Bidan Yuliani S.ST Banjarmendalan Kec. Lamongan Kabupaten Lamongan. Tahun 2019

\begin{tabular}{lllllll}
\hline \multirow{2}{*}{ Vulva Hygine } & \multicolumn{2}{l}{ Penyembuhan Luka Perineum } & \multicolumn{2}{l}{ Jumlah } \\
& \multicolumn{7}{l}{ Cepat } & \multicolumn{2}{l}{ Lambat } \\
\cline { 2 - 6 } & $\sum$ & $\%$ & $\sum$ & $\%$ & $\sum$ & $\%$ \\
Benar & 13 & $81,3 \%$ & 3 & $18,8 \%$ & 16 & $100 \%$ \\
Salah & 2 & $11,8 \%$ & 15 & $88,2 \%$ & 17 & $100 \%$ \\
Total & 15 & $45,5 \%$ & 18 & $54,5 \%$ & 33 & $100 \%$ \\
& & & $\alpha=0,05$ & & & \\
\hline
\end{tabular}

Berdasarkan tabel 4.7 diketahui bahwa ibu nifas yang melakukan vulva hygiene salah dan mengalami keterlambatan penyembuhan luka perineum 15 orang atau $88,2 \%$. Hasil perhitungan data dengan program SPSS dengan menggunakan uji ChiSquare $\alpha=0,05$ tidak memenuhi kriteria sehingga dilanjutkan dengan menggunakan uji Fisher's Exact Test digunakan nilai signifikan didapatkan $\mathrm{p}=0,000$ maka Hoditolak dan terdapat $\mathrm{H} 1$ diterima yang artinya ada hubungan Vulva hygiene dengan kecepatan penyembuhan luka perineum pada ibu nifas di BPM Bidan Yuliani S.ST Banjarmendalan 
Kec. Lamongan Kabupaten Lamongan. Tahun 2019.

\section{PEMBAHASAN}

Pembahasan dalam penelitian ini disusun sesuai dengan tujuan penelitian dan dari hasil statistik antara hubungan Vulva hygiene dengankecepatan penyembuhan luka perineum pada ibu nifas di BPM Bidan Yuliani S.ST Banjarmendalan Kec. Lamongan Kabupaten Lamongan. Tahun 2019

\subsubsection{Vulva Hygiene Pada Ibu Nifas Di BPM Yuliani S.ST}

Dari tabel 4.5 dapat diketahui bahwa sebagian besar ibu nifas $51,5 \%$ melakukan vulva hygiene salah.Vulva Hygiene merupakan perawatan pada daerah kemaluan ibu nifas yang bertujuan untuk menghindari terjadinya infeksi dan menjaga kesehatan vulva dan perineum (Timbawa, 2015). Teknik perawatan vulva hygiene yang salah pasca persalinan sangat menentukan lama penyembuhan luka perineum. Apabila teknik perawatan vulva hygiene salah terlebih masalah kebersihan maka penyembuhan luka akan berlangsung lama. Hal ini kemungkinan dipengaruhi oleh beberapa faktor yaitu pendidikan dan paritas.

Sesuai dengan tabel 4.3 didapatkan bahwa hampir sebagian ibu nifas $36,4 \%$ berpendidikan SMP/MTS melakukan vulva hygine dengan cara yang salah dikarenakan tingkat pendidikan sangat mempengaruhi seseorang dalam menerima informasi, seseorang yang mempunyai pendidikan yang tinggi akan memudahkan mereka untuk memperoleh gambaran keuntungan yang akan mereka peroleh setelah melakukan vulva hygiene dengan benar. Sebaliknya jika seseorang dengan pendidikan rendah, mereka akan sulit untuk memahami tentang pentingnya vulva hygiene dengan benar.

Menurut (Musrifatul,2008) Pendidikan adalah segala upaya yang direncanakan untuk mempengaruhi orang lain baik individu, kelompok atau masyarakat sehingga mereka melakukan apa yang diharapkan oleh pelaku pendidik. Pendidikan dapat berpengaruh terhadap pengetahuan seseorang dalam melakukan suatu tindakan berdasarkan pengetahuan yang dimiliki, dalam hal ini pendidikan sangat berpengaruh terhadap perilaku vulva hygiene yang benar, semakin tinggi pendidikan yang dimiliki oleh ibu maka ibu semakin mudah dalam mendapatkan informasi.

Dari tabel 4.2 didapatkan sebagian kecil 15,2\% ibu nifas memiliki jumlah satu orang anak. Hal ini dikarenakan kurangnya pengalaman ibu tentang cara melakukan vulva hygine yang benar pada masa nifas. Ibu yang memiliki anak lebih dari satu memiliki pengalaman tentang masa nifas lebik baik terutama pada perawatan vulva hygiene dibandingkan dengan dengan ibu yang baru memiliki satu anak, ibu yang baru mengalami masa nifas akan kurang mengetahui tentang cara menjaga kebersihan daerah kemaluan dan manfaat dari melakukan vulva hygiene yang benar.

Sesuai teori menurut Supariyanto, (2010) Paritas artinya lebih dari separuh ibu adalah multigravida maksudnya sudah sering melahirkan lebih dari satu kali, sedangkan ibu yang memiliki dua sampai tiga anak biasanya dengan pengalaman sebelumnya ibu 
dapat membersihkan kemaluannya secara benar.

\subsubsection{Penyembuhan Luka Perineum Pada Ibu Nifas Di BPM Yuliani S.ST}

Tabel 4.6 dapat diketahui bahwa sebagian besar ibu nifas $54.5 \%$ kecepatan penyembuhan luka perineum lambat. Kecepatan penyembuhan luka perineum yaitu mulai membaiknya luka perineum dengan terbentuknya jaringan baru yang menutupi luka perineum dalam jangka waktu 6-7 hari post partum, sedangkan penyembuhan luka perineum dikatakan lambat jika dalam waktu lebih dari 7 hari post partum belum terbentuk jaringan baru yang menutupi luka perineum. Lambat, jika luka basah, perineum belum menutup dengan baik sehingga dapat menyebabkan infeksi (Masa'dah, 2010). Hal ini dipengaruhi oleh pekerjaan dan usia ibu.

Kurangnya mobilisasi dini pada ibu nifas dimana ibu takut nyeri pada luka jahitan perineum sehingga menghambat penyembuhan luka perineum sedangkan ibu yang melakukan mobilisasi sesuai dengan tahapan akan lebih membantu mempercepat penyembuhan luka perineum. Selain itu dari data umum diketahui bahwa pekerjaan dan usia juga mempengaruhi penyembuhan luka perineum, dimana hampir sebagian ibu nifas $48,5 \%$ bekerja sebagai ibu rumah tangga. Hal ini sesuai dengan pendapat Halminton, (2008) mobilisasi yang dilakukan sesuai tahapan antara lain gerakan miring kiri dan kanan serta berjalanjalan ringan sehingga membantu mempercepat penyembuhan luka perineum.
Tingkat percepatan luka perineum di PMB Yuliani S.ST berlangsung lambat yang salah satunya dipengaruhi oleh perilaku vulva hygiene yang salah seperti baru mengganti pembalut saat terasa penuh sehingga penyembuhan luka perineum semakin terhambat karena keadaan luka jahitan yang lembab.

Salah satu faktor yang mempengaruhi penyembuhan luka menurut Smeltzer (2010) yaitu kurangnya mobilisasi dini, cara perawatan luka yang kurang benar sehingga dapat menghambat perepatan tepi luka dan mengganggu penyembuhan luka pada perineum.

Selain itu menurut tabel 4.1 sebagian kecil ibu nifas berusia $<21$ tahun yaitu $9,1 \%$ dan berusia $>35$ tahun sebanyak 24,2\%. Hal ini dikarenakan usia ibu nifas yang berusia <21 tahun dan >35 tahun akan mengalami keterlambatan penyembuhan luka karena pada usia $<21$ tahun dan >35 tahun sering terjadi penyulit (komplikasi) yang berupa infeksi baik pada ibu maupun bayi.

Sesuai teori menurut Sukijonatoatmojo, (2010), usia reproduksi yang aman untuk kehamilan dan persalinan adalah 2030 tahun sebab diusia $<20$ tahun dan $>35$ tahun sering terjadi penyulit (komplikasi) baik pada saat kehamilan, persalinan maupun masa nifas.

\subsubsection{Hubungan Vulva Hygiene dengan Penyembuhan Luka Perineum Pada Ibu Nifas di BPM Yuliani S.ST \\ Dari hasil penelitian} menunjukkan bahwa hampir seluruh ibu nifas81,2\% melakukan vulva hygiene salah dan sebagian kecil $18,8 \%$ melakukan vulva hygine 
dengan benar. Disamping itu hampir seluruh ibu nifas $88,2 \%$ mengalami penyembuhan luka perineum yang lambat dan sebagian kecil 11,8\% mengalami penyembuhan luka perineum yang cepat.

Hasil perhitungan data dengan program SPSS dengan menggunakanUji Fisher's Exact Test digunakan nilai signifikan didapatkan $\mathrm{p}=0,000$ dan terdapat $\mathrm{H}_{1}$ diterima yang artinya ada hubungan vulva hygiene dengan kecepatan penyembuhan luka perineum pada ibu nifas di PMB Yuliani S.ST Banjar mendalan Kec. Lamongan Kabupaten Lamongan. Tahun. Kecepatan penyembuhan luka perineum pada ibu nifas dapat dipengaruhi oleh bagaimana cara perawatan perineum dari setiap individunya.

Dari data di atas dapat disimpulkan bahwa terdapat hubungan vulva hygine dengan lama penyembuhan luka perineum. Hal ini dikarenakan vulva hygine dapat mencegah terjadinya infeksi yang dapat menyebabkan lamanya penyembuhan luka perineum. Hal ini sesuai dengan teori penyembuhan luka menurut Smeltzer (2010), personal hygiene atau vulva hygiene sangat mempengaruhi penyembuhan luka perineum, jika kebersihan diri pada ibu postpartum kurang terjaga akan menyebabkan adanya infeksi. Personal hygiene atau kebersihan diri yang kurang juga dapat memperlambat penyembuhan, hal ini dapat menyebabkan adanya benda asing seperti debu dan kuman. Pada prinsipnya, masa nifas perlu di jaga kebersihan vaginapada masa nifas perlu dijaga yaitu banyak darah atau lochea yang keluar dari vagina, adanya luka didaerah perineum yang bila terkena kuman dapat menjadi infeksi,vagina merupakan organ terbuka yang mudah dimasuki kuman kemudian menjalar ke Rahim. Luka perineum akibat episiotomy, rupture atau laserasi merupakan daerah yang tidak mudah. Pengetahuan ibu tentang perawatan setelah persalinan sangat menentukan lama penyembuhan luka perineum. Apabila pengetahuan ibu kurang terlebih masalah kebersihan maka penyembuhan lukapun akan berlangsung lama.

Berdasarkan penelitian lain Puspitarani (2010) terdapat hubungan vulva hygiene dengan penyembuhan luka perineum di Puskesmas Mergangsan dan Jetis Kota Yogyakarta. Dari 24 responden terbagi menjadi 2 kategori yaitu responden yang kesembuhan lukanya baik sebnayak $87,5 \%$. Hasil uji statistic Sperman Rho didapatkan nilai korelasi 0,659 dengan signifikan $\mathrm{p}$ sebesar $0,000(\mathrm{p}<0,05)$ yang artinya $\mathrm{Ho}$ ditolak dan $\mathrm{H}_{1}$ diterima.

Berdasarkan penelitian menyimpulkan bahwa ada hubungan antara vulva hygiene dengan penyembuhan luka perineum. Hal ini menunjukkan bahwa vulva hygiene yang benar akan mempengaruhi percepatan pada penyembuhan luka perineum pada ibu nifas.

\section{PENUTUP}

\subsection{Kesimpulan}

1. Sebagian besar ibu nifas di BPM Yuliani S.ST melakukan vulva hygiene dengan cara yang salah.

2. Sebagian besar ibu nifas di BPM Yuliani S.ST kecepatan penyembuhan luka perineum mengalami keterlambatan.

3. Terdapat hubungan antara vulva hygiene dengan 
kecepatan penyebuhan luka perineum, dimana tindakan vulva hygiene yang benar dapat mempercepat penyembuhan luka perineum.

\subsection{SARAN}

Berdasarkan kesimpulan diatas beberapa upaya yang perlu diperhatikan diantaranya:

1) Bagi Profesi Kebidanan

Diharapkan hasil penelitian ini dapat dijadikan sebagai bahan pengembangan rencana asuhan kebidanan guna meningkatkan mutu pelayanan yang berkaitan dengan informasi pada ibu nifas tentang manfaat vulva hygiene terhadap kecepatan penyembuhan luka perineum.

2) Bagi Peneliti yang Akan Datang Diharapkan hasil penelitian ini dapat dijadikan sebagai studi pendahuluan untuk mengembangkan penelitian dengan populasi yang lebih banyak lagi dan dengan menggunakan variabel yang lain seperti nutrisi, psikologi ibu dan mobilisasi.

3) Bagi Institusi Pendidikan

Diharapkan hasil penelitian ini dapat digunakan sebagai bahan evaluasi bagi mahasiswa dalam melanjutkan program penelitian.

\section{4) Bagi Responden}

Diharapkan hasil penelitian ini dapat menambah pengetahuan dan pengalaman ibu dan keluarga agar dapat melakukan secara mandiri untuk waktu yang akan datang dan menjadi informasi yang bisa disampaikan kepada ibu nifas yang mengalami masalah yang sama.

\section{DAFTAR PUSTAKA}

Abd. Nasir, Abdul Muhith, Ideputri (2011), Metode Penelitian Kesehatan, Mulia Medika, Yogyakarta

Abd.Wahid. 2012. Perawatan Manternitas, edisi 2, Jakarta: ECG Ambarwati, E, Retna.2010. Asuhan Kebidanan Nifas. Yogyakarta: Nuha Medika

Anggraini, Yetti. 2010. Asuhan Kebidanan Masa Nifas. Yogyakarta: Pustaka Rihama.

Arikunto, 2006.Prosedur Penelitian Suatu Pendekatan Praktik. Edisi Revisi VI. Jakarta. Rineka Cipta.

Arikunto, Suharsim. 2010. Prosedur Penelitian Suatu Pendekatan Praktik. Jakarta: Rineka Cipta.

Aziz, Alimul, 2010. Metode Penelitian Kebidanan Dan Tehnik Analisi Data. Jakarta: Salemba Medika

Azwar, Azrul. 2014. Metode Penelitian. Binarupa Aksara Publisher: Tangerang Selatan

Bahiyatun.2009. Asuhan Kebidanan Nifas Normal.Jakarta: EGC.

Boyle, Maureen. 2009. Pemulihan Luka. Jakarta: EGC

Depkes RI. 2017 Gambaran Angka Kejadian Ruptur Perineum di Indonesia. Depkes Press, Jakarta. 
Ekaputra, E, 2013, Evolusi Manajemen Luka, CV. Trans Info Media, Jakarta.

Eny, Retna dkk. 2009. Asuhan Kebidanan Nifas. Jogjakarta: Mitra Cendikia offset

Farer, Helen. 2004. Perawatan Manternitas, edisi 2, Jakarta: ECG

Friedman, Marilyn M. 2010. Buku Ajaran Keperawatan: Riset, Teori dan Praktek. Jakarta: EGC

Hidayat, A. Aziz Alimul, 2014, Pengantar Konsep Dasar Keperawatan, Jakarta : Salemba Medika

Hidayat, A. Aziz Alimul, 2017, Perilaku Konsep Dasar Vulva hygiene, Jakarta : Salemba Medika

Hidayat, A.Alimul. 2009. Metode Penelitian Keperawatan Dan Teknik Analisis Data. Jakarta. Salemba Medika.

Janna, Nur. 2017. Buku Ajaran Asuhan Kebidanan Nifas. Yogyakarta: nuha Medika

Mas'adah, S. 2010. Hubungan Antara Kebiasaan Berpantang Makanan Tertentu Dengan Penyembuhan Luka Perineum Pada Masa Nifas.

Musrifatul, Uliyah. 2008. Buku Ajar AsuhanKebidanan 3 Nifas. Yogyakarta: Medical Book
Notoatmodjo,S. 2010. Metodologi Penelitian Kesehatan. Jakarta: Rineka Cipta

Notoatmodjo. 2010. Metode Penelitian Kesehatan. Jakarta : PT. Rineka Cipta

Nugroho, dkk .2014.Buku Ajar AsuhanKebidanan 3 Nifas. Yogyakarta: Medical Book

Nugroho, T., dkk. 2014. Buku Ajaran Asuhan Kebidanan Nifas (askeb 3). Yogyakarta : Nuha Medika

Nursalam, 2008.Konsep Dan Penerapan Metodologi Penelitian Ilmu Keperawatan, Jakarta : Salemba Medika

Nursalam, 2008.Konsep Dan Penerapan Metodologi Penelitian Ilmu Keperawatan, Jakarta : Salemba Medika

Oxorn, $\mathrm{H}$ dan William $\mathrm{R}$ F. 2010.Ilmu Kebidanan Patologi \& Fisiologi Persalinan. Yogyakarta: ANDI OFFSET.

Prawirohardjo Sarwono. 2011. Ilmu Kebidanan 2008. Jakarta: PT. bina pustaka

Rukiyah, A.I, Yulianti, L.2014. Asuhan Kebidanan IV (Patologis). Jakarta : Trans Info Media

Saifuddin.2012. Pelayanan Kesehatan Maternal Dan Neonatal.Jakarta : PT. Bina 
Pustaka
Prairohardjo.

Saleha, Siti. 2009. Asuhan Kebidanan Pada Masa Nifas. Jakarta: salembamedika

Smeltzer, S.C \& Bare, B.G, 2010, Buku Ajar Medical Bedah Edisi 8 Volume 2, alih bahasa kuncara, H.Y,dkk, EGC, Jakarta

Suherni,dkk. 2009. Asuhan Kebidanan Pada Masa Nifas. Jogjakarta: fitramaya

Sulistyowati, Ari. 2015. Buku Ajar Asuhan Kebidanan pada Ibu Nifas. Yogyakarta: C.V Andi Offset

Timbawa, S. dkk. 2015. Hubungan Vulva hygiene Dengan Pencegahan Infeksi Luka Perineum Pada Ibu Post Partum di RS Pancaran Kasih GMIM Manado, (Online) Vol 3, No 1 , (https://ejournal.unsrat.ac.id/ diakses 16 September 2018

Wiknjosastro. 2010. Buku Panduan Praktis Pelayanan Kesehatan Maternal dan Neonatal, Edisi 1. Cet. 12.Jakarta : Bina Pustaka

World Health Organization.Definisi Sehat WHO: WHO; 1947 [cited 201720 oktober]. Available from: www.who.int.
Yanti , damai.dkk.2011. Asuhan Kebidanan Masa Nifas. Bandung: refikaaditama

Yeyen, Ay 2010.Asuhan Kebidanan I (kehamilan). Jakarta: Media Trans Info Medika. 